\title{
アゾベンゼン系物質の添加によるボイド放電の減少効果
}

\author{
非会員岡田めぐみ正員山野芳昭 (千菜大)
}

\section{Reduction of Void Discharges by additive of Azo-Benzene Compound}

\author{
Megumi Okada, non-Member and Yoshiaki Yamano, Member
}

(Chiba University)

The void wall in HDPE was modified by additive to reduce the void discharge. The additives used were four kinds of azobenzonic materials; azobenzene, $p$-nitroazobenzene, $p$-aminoazobenzene and nitrobenzeneazo-resolcinol.

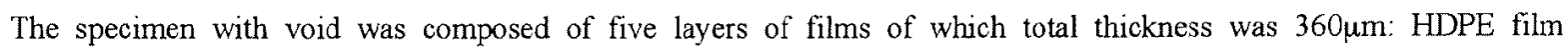
(thickness of $100 \mu \mathrm{m}$ ) with three holes of $1 \mathrm{~mm} \phi$ (voids) was sandwiched between the HDPE films with additive; Furthermore, they were sandwiched between HDPE films of $100 \mu \mathrm{m}$ thick. The voids in specimen were a cylindrical configuration of $1 \mathrm{~mm} \phi$ in diameter and $100 \mu \mathrm{m}$ in height. The HDPE film with additive (thickness of 30 $\mathrm{mm}$ ) was prepared by solution casting method. The specimen was set between plane electrodes. It was confirmed that PD in void was remarkably reduced by using the film with additive. The reduction of PD in void was observed in all kinds of additive used. The effective concentration of the additive in HDPE lies from 0.05 to $0.1 \mathrm{wt} \%$. The PD for the specimen with additive was reduced to as low as about $20 \%$ of that for the specimen without additive under the applied voltage of $1.55 \mathrm{kV}$. The reduction of $\mathrm{PD}$ in void was observed in all kinds of additive used. The mechanisms for the reduction in the PD are discussed focusing on the two points. One is the prevention of secondly electron emission from void wall due to the excitation of additive. Another is the prevention of electron detachment from the wall due to the modification on characteristics with electrification of the wall by the additive.

キーワード : ボイド放電, 部分放電. 添加剤, アゾベンゼン

\section{1.はじめに}

高電圧機器の絶縁部におけるボイド放電の発生は、電気 トリ一の発生や絶縁破壊等につながり、高電圧機器の絶縁 信頼性䘮低下させる要因となる。そのため、ボイド放電の 発生を抑制する方法は古くから検討されている。たとえば、 絶縁物老形成する際に減圧・脱気を行うことによって、ボイ ドの数を極力少なくする方法がある(1)。また、絶縁部中に半 導電性の添加剤を混入し、添加剤のブリード効果によって ボイド壁の表面抵抗の减少を図り、ボイド内の電界強度を 弱めてボイド放電が発生しにくい状態にする方法もある(2!。 しかし、何らかの原因でボイドが生成され、さらにボイド 放電が発生する状況においても、ボイド放電の発生数や強 度を減少させるための方法を検討した例は少ないと考えら れる。

ボイド放電は、密閉空間で対向する2つの絶縁物表面の 間で発生寸る部分放電である。ボイド放電が発生すると、 陽極あるいは陰極上なる絶縁物表面（ボイド壁）に電荷 (ボイド放電により発生したもの) が带電する。陽極に相
当するボイド壁には負電渮が带電する。印加電界が反転す ると、ボイド壁に带電した負電荷には、今度はボイド壁か らボイド空間に向かう力が作用する。ボイド放電の発生は、 主として、ボイド空間内招ける電子なだれ等の発生に基づ く々考えらるので(3)、もしボイド壁に帯電している負電荷 のうち電子がボイド空間八放出されれば、これが新たなボ イド放電の発生へつながるであるう。さらには、隍極に相 当寸る䋓縁物表面加らの二次電子放出作用もボイド放電の 発生につながるものと考えられる。このようなことを考え， ると、ボイド壁からボイド空間への電子の放出（帯電電子 の放出や二次電子の放出）を何らかの方法で抑制できれば、 ボイド放電が発生する電界強度下においても、ボイド放電 を減少させることができる可能性があると考えられる。

本研究は、絶粶物（ポリエチレン:PE）に添加刜を混入す ることにより、ボイド壁面の電気的特性を改質し、発生す るボイド放電（以下では、PD と略記する。）を低堿させる ことを目的とした。添加剤としては、アゾベンゼン系の物 質を用いた。筆者の一人は以前アゾベンゼン系添加剤を用 
いてポリエチレンの緦縁破壊強度の向上を試みたこ上があ $ろ^{(4.5)}$ 。アゾベンゼン系の物質は、同じ分子骨格でベンセン 環に電子受容基や電子供与基を付加したものが試楽上して 多数存在する。電子供与基あるいは受容基を持つアソベン ゼン系物質を PEに添加することで、電子のボイド壁への带 電特性(トラップ特性)を変化させることができるものと期待 できる ${ }^{(6,7)}$ 。さらには、アゾベンセン系物質に存在するベン ゼン環は、そのル電子効果により、絶核物表面の二次電子 放出効果を抑制できる可能性功考えられる。このような観 点のもとに、本報告では 4 種類のアゾベンゼン系物質を添 加した PE を用いて、アゾベンぜン系添加剂によるボイド放 電の減少効果について検討を行った。

\section{2. 実験方法}

〈2・1〉添加剤および試料試料の構成を図 1 に示す。 試料は合計 5 枚の円形フィルムを重ねたものである。フィ ルム B および D は HDPE(高密度ポリエチレン)製で、片面 を添加剤の入った HDPE でコーティングしてある。コーテ イングの厚さは 10um である。図ではコーティング部分を 黒で示してある。これらフィルムの愿さはコーティングも 含めて $30 \mu \mathrm{m}$ である。フィルムCに怔、图の上うに3つの 穴 $(\mathrm{h}: 1 \mathrm{~mm}$ ф) 在 $10 \mathrm{~mm}$ 間隔で空けてある。フィルム $\mathrm{B}$ 上 $\mathrm{D}$ のコーティング面がフィルムCに接触するように重ね、こ れらをさらにフィルム $\mathrm{A}$ とフィム $\mathrm{E}$ で挟んである。なお、 フィルム $\mathrm{A} 、 \mathrm{C}$ およ゙ $\mathrm{E}$ の厚さは、それでれ $100 \mu \mathrm{m}$ である。 この試料のボイドは、フィルム $\mathrm{C}$ に空けた 3 力所の穴と、 その穴の上面上下面が添加剂入り HDPEの表面で塞がれた 状態で形成されている。な掞、本実験で用いたポリエチレ ンはすバて HDPE であるので、以後性これを PE と略記す る。

添加剤入り PE は、溶液キャスティング法によりフィルム BとDの表面にコーティングを行った。PEペレット（エー スポリマー:B5031）に重量比で $0.01 〜 0.1 \%$ \%アソベンゼン

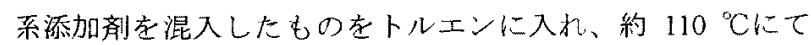

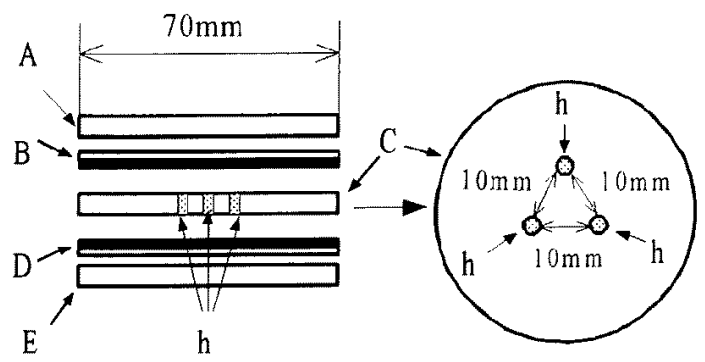

図 1 試料の構成

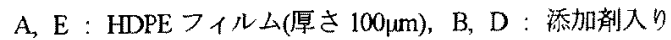

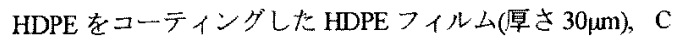

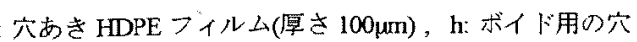

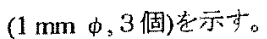

Fig.1 Construction of specimen (l)<smiles></smiles>

Azobenzene (Az)

(2)

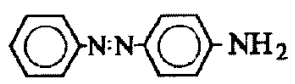

p-Aminoazobenzene $\left(A z_{-} a\right)$

(3)

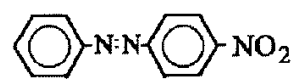

p-Nitroazobenzene $\left(A z_{-} n\right)$

(4)<smiles></smiles>

p-Nitrobenzeneazo-resorcinol (Az,ha)

図 2 使用したアソンベンゼン采添加鼡

Fig.2 Azo-benzoic additives used.

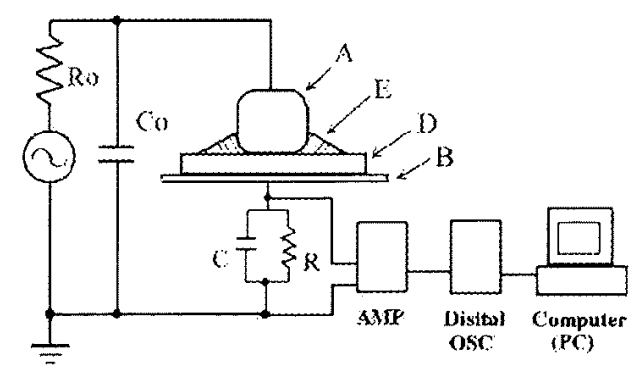

図 3 ボイド放電の測定系

$\mathrm{A}$ : 高電圧電極、 B: 平板電極， D: 試料， E；エポキシチール ド, AMP: 増幅器( $(30 \mathrm{~dB}, \mathrm{DC} \sim 10 \mathrm{MHz}), \mathrm{C}, \mathrm{R}:$ 険出インピー ダンス $(\mathrm{C}=1000 \mathrm{pF}, \mathrm{R}=3 \mathrm{k} \Omega), \mathrm{C}_{0}=(4700 / 3) \mathrm{pF}, \mathrm{R}_{v}=680 \mathrm{k} \Omega$

Fig.3 Experimental setup for void discharge.

加熱・摚找し、PEフイルム上に展開した捘、乾燥させた。ま た比較のため、添加剤を混入しない状態のトルエン溶融 $\mathrm{PE}$ をPEフィルム上に展開して乾燥させたものも作製した。

添加剤として実験に用いた 4 種類のアゾベンゼン柔物質 を図 2 に示す。これ以降、本論文では各添加剤を図 2 に示 してある略号で呼ぶことにする。使用した添加剤は、アゾ 基に付く2つのペンゼン環に何も付加されていない Az、Az に電子供与基 $\left(\mathrm{NH}_{3}\right)$ 在 1 つ導入した $\mathrm{Az}_{-} \mathrm{a}$ 、電子受容基 $\left(\mathrm{NO}_{2}\right)$ を1 つ導入した $\mathrm{Az}_{-} \mathrm{n}$ 、をして $2 つ の$ 電子供与基 $(\mathrm{OH})$ と $1 つ$ の電子受容器 $\left(\mathrm{NO}_{2}\right)$ 在導入した $\mathrm{Az}$.hn である。

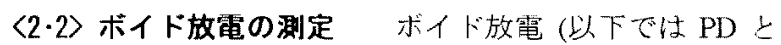
略記する。）の測定は、図3に示扵測定柔で行った。高電圧 電極(図中の A)は $30 \mathrm{~mm} \phi$ のアルミ製円柱電極で、端部は曲 率 $10 \mathrm{~mm}$ で丸めてある。高電圧電極端部から部分放電が発 生するの孝防止するため、端部はエポキシ樹脂でたールド してある(図中の $\mathrm{E})$ 。高電圧電極と平板電極(B)の問に、試料 (D)を抑入した。

挨出インピーダンス（図中の $\mathrm{C}, \mathrm{R}$ ）により検出された $\mathrm{PD}$ 


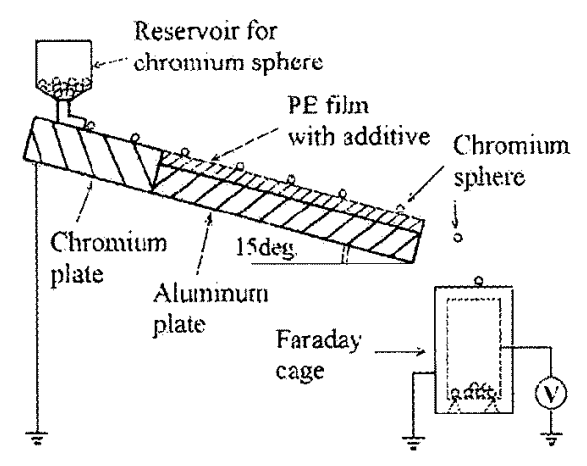

図 4 接触带電測定装置

Fig.4 Experimental setup for measurement of contact charging.

信号は、增幅器(AMP)とデジタルストレージオシロスコー プ(Digital OSC; HP54510B)を経て、PC に蓄積される。一回の 操作で、交流印加電圧 $(50 \mathrm{~Hz})$ のサイクル間の $\mathrm{PD}$ 信号を PCに取り込む。1つの試料につき、印加電圧 1 サイクル間 の $\mathrm{PD}$ パルスを、30 秒間隔で計 300 サイクルの測定を行い、 それらをデータとして使用した。なお、本奏験では、 $2 \mathrm{pC}$ 以上の放電電荷定持つパルスを $\mathrm{PD}$ パルスとして取り报っ t。

測定時の印加電圧は、PD 開始電圧(約 $1.4 \mathrm{kV}$ )から $2 \mathrm{kV}$ の 範囲である。PD 開始電圧は、電圧印加後 5 分間に $2 \mathrm{pC}$ 以上 の PDパルスが検出される最低の電圧とした。

なお、試料は合計 5 枚の PE フィルムを重ねたものである ので、各フィルム間のわずかな陌間から PD が発生するこ とも考えられる。そこで、図 1 中のC で示した穴あきフィ ルムを、穴なしフィルムに置き換えて、PDの測定を行った。 その結果、穴なしフィルムを用いた場合に検出される PD パルス数は、実験を行った印加電圧の範囲で、穴の空いた フィルムを用いた場合の1/100以下であった。すなわち本実 験で用いる試料では、フィルム間の微小間隙で発生寸る PD を無視できるものとした。

〈2・3〉絶縁物表面の帯電特性に及ぼす添加剤の影㫪の評

価添加剂の混入によって生じる PEフィルムの带電特性 の変化を調べるため、図 4 に示寸装置を使ってクロム球と 添加剂入り PEフィルムとの接触带電特性を剆定した。試料 は厚さ20um の添加剂入り PEフィルムで、アルミ板上に溶 液キャスティング法で作成したものである。図のように、 試料及びクロムメッキ板は $15 \mathrm{deg}$ 傾けて南る。リザーバー にあるクロム球 $(1 \mathrm{~mm} \phi$, 総重量 $3.0 \mathrm{~g})$ 和らクロムメッキ板上 (ともに接地してある)を転がった後、添加鼡入り PEフィル ム上を転がり、ファラデーケージに入る。添加郕入り PEフ イルムとクロム球とは、接触带電によりお互いに異符号の 電荷が等量帯電するはずである。ファラデータージの電圧 を測定することにより、フィルム表面に带電した電荷量を 求內た。

\section{3. 実験結果と検討}

〈3・1〉添加剂入りフィルムを用いた試料のPD特性 図 5 は PD パルスとその発生位相（印加電圧の位相）との関 係を、添加剤の種類毎にプロットしたものである。印加電 圧にして 300 サイクル分の PD パルスを積算して図に示し ている。測定時の印加電圧は各試料上も $1.55 \mathrm{kV}$ であり、添 加剤の濃度は各試料とも $0.05 \mathrm{wt} \%$ あ゙あ。図中の正弦波は印 加電圧の位相を示している。

図の各グラフに示すドットの密度老比較すると、添加剤 入りフィルムを用いた試料（以後、添加試料と略記）の PD パスの発生数注、無添加フィルムを用いた試料（以後、 無添加試料上略記。）上比較して大きく减少していることが わかる。PDパスの最大放電電荷については、添加剤の種 類一の依存性は顕著ではなく、なおかつ無添加試料之比心゙ て大きな違いは見られない。

図6 は添加剤の濃度とPD の積算放電電荷との関係を示 したものである。図が煩雑になるのを防ぐため、代表的な 2 種類の添加試料と無添加のデータについてのみ示してい る。PDの積算放電電荷とは、測定した印加電圧 300 サイク ル分の正負 PD パルスについて、それらの放電電荷の絶対 值を積算したものである。各添加試料とも添加剤の濃度が 0.05〜0.5W†\%あたりで頙著な减少効果を発揮する傾向にある。 図には特に示さないが、PDパルス数の積算についても、図
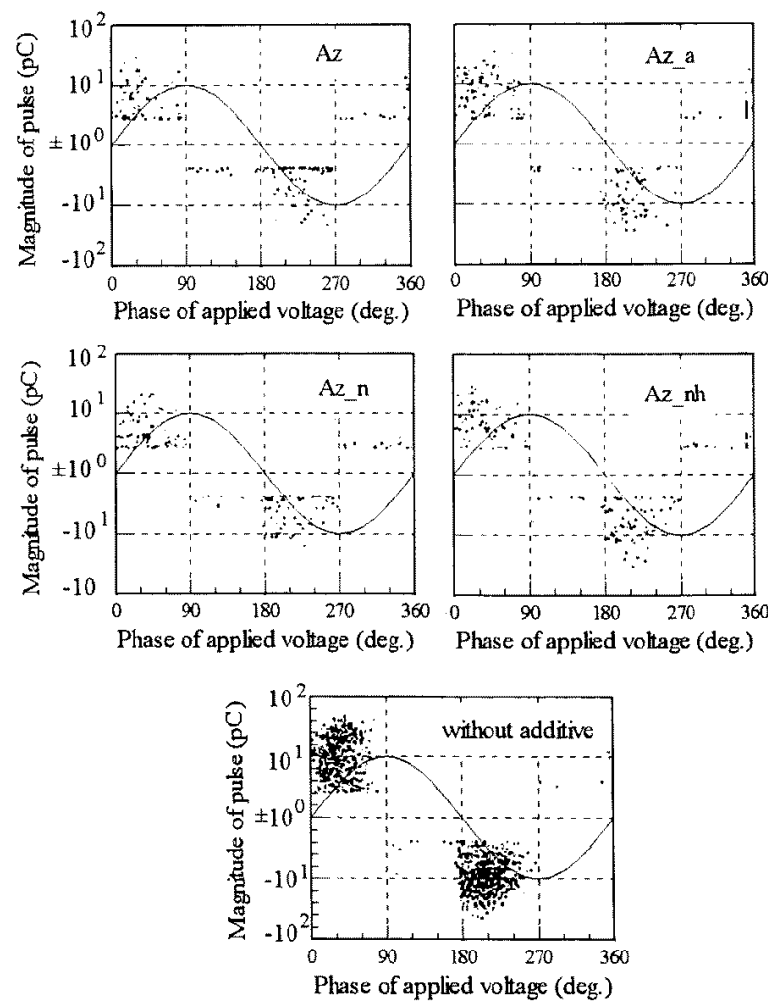

図 $5 \mathrm{PD}$ パルスの放電電荷上印加電圧位相との関倸

Fig. 5 Relation between magnitude of PD pulse and appearance phase of applied voltage. 


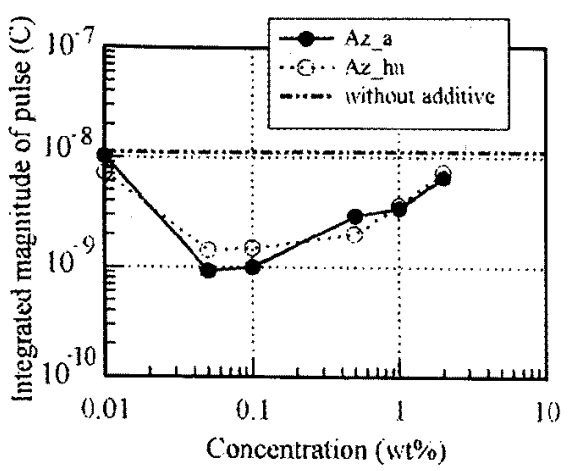

図6 PDパルスの積算放電電荷と添加剤濃度 亡の関係

Fig.6 Relation between integrated magnitude of the $\mathrm{PD}$ and concentration of additive.

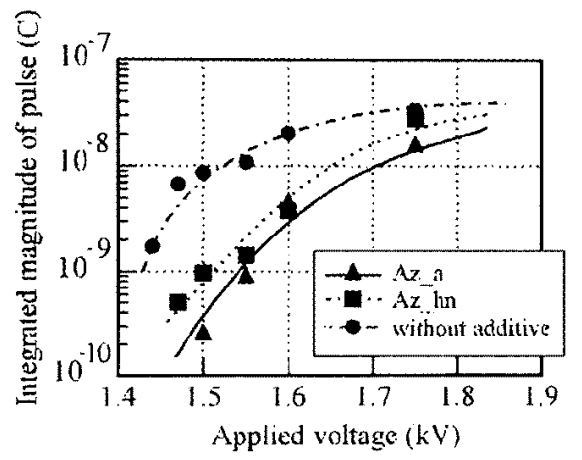

図 7 PD パルスの積算放電電何と印加電王 との関倸

Fig.7 Relation between integrated magnitude of $\mathrm{PD}$ pulse and applied voltage.

6 の放電電荷の積算と同様の傾向を示し、0.05〜0.5wt\%あた りの添加濃度で顕著な减少効果を示す。なお、図6 を見る 上、添加濃度が高いと PD パルスの城少効果が少なくなる 傾向にある。添加濃度が $0.5 \mathrm{w}$ \% \% 越えるとフィルム表面に 局部的な添加剤の析出が見られることから、この傾向は添 加剂と PE との相溶性に原因があると考えられる。

図 7 は、印加電圧上PD パルスの積算放電電荷との関倸

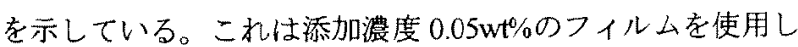
たときのデータである。図が煩雑になるのを防ぐため、代 表的な 2 種類の添加試料と無添加試料のデータについて示 している。図 7 に示寸ように、印加電圧が高くなると、添 加試料による PD の减少効果が低下する傾向にある。なお、 PD 開始電圧は、添加試料、無添加試料上もに、約 $1.4 \mathrm{kV}$ で ある。したがって、添加試料における PD の減少は、PD 開 始電压付近の印加電圧で効果が現れていることになる。

図 8 は、PD ハルスの積算放電電荷上積算発生数を各添加 試料毎に示したものである。データは、添加剤濃度 $0.05 \%$ 、 印加電圧 $1.55 \mathrm{kV}$ のときのものである。図に示すように、各

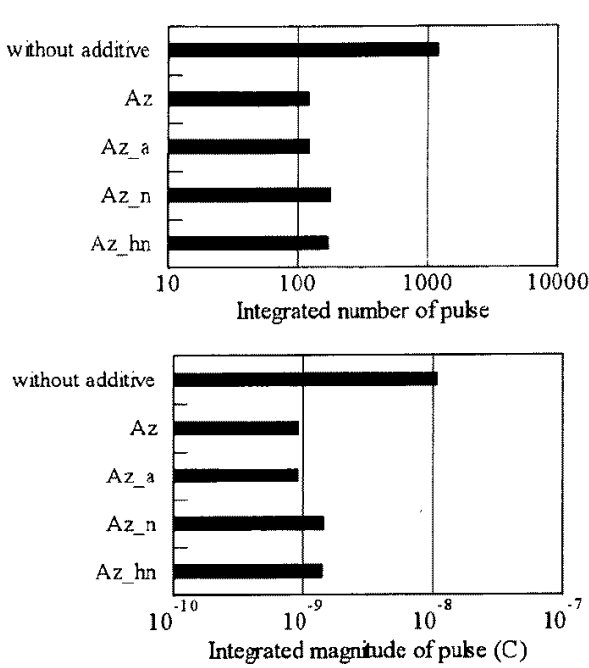

図 8 添加剤による $\mathrm{PD}$ パルスの積算放電電荷 及ひ積算発生数の変化

Fig. 8 Changes in integrated magnitude and number of $\mathrm{PD}$ by additive.

添加試料における PD パルスの積算放電電荷と積算発生数 は、無添加試料と比べて减少している。積算放電電荷と積 算発生数ともに無添加試料の15〜20\%程度まで城少してい る。 $\mathrm{PD}$ パルス減少効果の添加郕の種類への依存性は、顕著 ではない。しかし、AzとAzaの方が $\mathrm{Az}_{-} \mathrm{n}$ 上Az_hnよりも、 减少效果が若干高い傾向を示している。

〈3-2〉添加試料におけるPD城少の要因添加姷試料に おけるボイドは、ボイド壁の PEに添加戍が混入されている ことが異なるのみで、無添加試料におけるボイドと形状,大 きさは同じである。したがって、前項で示した添加剤試料 における PD の低減効果は、ボイド壁の電気的特性の変化 が何らかの要因上なっているものと考えられる。図 7 に示 した実験結果からもこのことが間接的に裹付けられる。す なわち、印加電圧が上昇するとボイド内の空間で電離等が 優势になり、PD の発生数・放電電荷が增加する。その結果、 ボイド壁面における PD 減少効果が相殺されるため、図 7 に示すように印加電圧が高くなると PD の減少効果が低下 するものと考えられる。このようなことから、本項では添 加剤入りボイド壁が PD 減少に果たす要因について考えて みる。

$\mathrm{PD}$ がボイド内で発生すると、PD に起因したUV 光が発 生する。UV 光がボイド壁面八照射される上、ボイド壁から 二次電子が放出されることが考えられる。すなおち、壁面 近くのPEバルク内にトラッブされていた電子が UV 光のエ ネルギーを得て、二次電子としてボイド壁から放出される こよが考えられる。また、PDの発生によってボイド空間で 発生した正イオンが㓌極に相当するボイド壁面に衝突する 上、トラッブされている電子が、正イオンの連動エネルギ 一を得るこよによってもボイド壁面から二次電子として放 


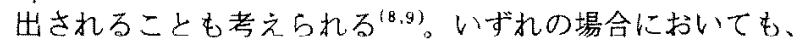
二次電子がボィド壁から放出されると、それが更なる PD の発生を促進させるであるう。アゾベンゼン系物質を添加 したボイド壁面において、もし添加剤分子の励起作用によ り UV光のエネルギーあるいは正イオンの運動エネルギー が吸収されれば、二次電子放出は抑制されることになり、 それが PDの减少に効果を果たすことが考えられる。

次にボイド壁面の電荷の带電特性の変化と PD との関係 について考える。使用した添加鼡によって、ボイド壁面の 帯電特性が変化することが考えられる。ボイド壁の帯電特 性の変化は、以下に述べる理由により PD の発生特性に影 響を与えると考えられる。すなわち、PDの発生によって、 正極側に相当するボイド壁面には負電荷が带電する。ボイ ド内の電界が反転すると、帯電している電子の一部がボイ ド壁面から離れ、対向する壁面に向かって運動寸るである ら。そして、電子の運動に起因して電子なだれが生じると、 さらなる $\mathrm{PD}$ の発生へとつながる。もし、ボイド壁面の带 電特性の変化によって帯電電子がボイド壁面から離れにく くなれば（電子がボイド壁に強くトラッブされれば）、PD の発生は减少するであるう。

最後に、添加剤の混入によりボイド壁面の表面抵抗が低 下することも考えられる。その結果、ボイド内の電界が緩 和され、PDの発生が抑制される可能性がある。しかし、本 実験で作成した添加剂入りPEの表面抵抗率は、全ての添加 㓮入り PEに括いて、1 $10^{14} \Omega$ 以上 $\left(20^{\circ} \mathrm{C} ， 50 \% \mathrm{RH}\right)$ の值であ った。また、PD 発生電圧は、添加剤の有無や種類による顕 著な変化は見られず、約 $1.4 \mathrm{kV}$ であった。したがって、本 奏弱の添加試料に打いて、PD の低城効果はボイト壁の表面 抵抗の低下に起因しているとは考えにくい。

以下では、添加郕分子の励起効果と添加剤によるボイド 壁面の带電特性の变化とに焦点を当てて、ボイド壁面にお ける添加剂入り PEが PDの発生や成長の抑制に果たす役割 を検討する。

\section{〈3.3〉添加剤分子の镹起作用によるPD成少の可能性}

前項でも述べたように、ボイド壁から二次電子が放出され ると、それが新たな PD の発生を促進させることになる。 ボイド壁面が添加剤入り PEの場合は、添加剂分子の励起作 用により UV 光のエネルギー或いは正イオンの運動エネル ギーが添加剤分子に吸収されれば、それによって二次電子 放出が抑制されることが考えられる。本項では、添加剂分 子の励起作用に基ぶく、ボイド壁面からの二次電子放出の 抑制効果について検討を行う。

実験に使用したアゾベンゼン系添加剂の UV 光吸収特性 老図 9 に示寸。各添加剤の最大吸収を示寸波長は、図に示 すように、およそ $320 \mathrm{~nm} \sim 450 \mathrm{~nm}$ の範囲にある。添加剤の 励起エネルギーをUV 光の吸收波長から換算寸ると、その 範囲は約 $2.8 \mathrm{eV} \sim 3.8 \mathrm{eV}$ となる。一方、PEにトラップされ ている電子の光による放出も、拈よそこの範用のエネルギ 一によって生じると報告されている ${ }^{(19)}$ 。したがって、添加

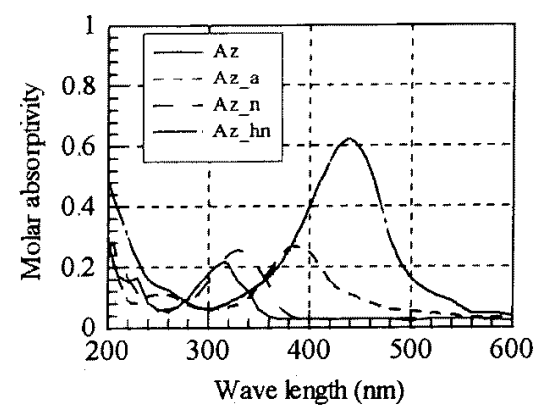

図9 添加剤のUV吸収スペクトル (エタノール溶液にて測定。)

Fig.9 UV spectrum of absorption for additive.

剤分子の励起作用により、UV光によるボイド壁からの二次 電子放出が抑制されることが十分に考えられる。

次に、このような励起エネルギーをもつ添加剤の入った ボイド壁に正イオンが衝突する場合を想定してみる。印加 電圧を $1.55 \mathrm{kV}$ とすると、奏験試料中のボイド内の電界は約 $47 \mathrm{kV} / \mathrm{cm}$ となる。空気分子の平均自由行程を $0^{\circ} \mathrm{C}, 1$ 気压で 約 $6.06 \times 10^{-6} \mathrm{~cm}$ とすると(1)、平均自由行程内で正イオンは約 $1.6 \mathrm{eV}$ の運動工ネルギ一を得ることになる。したがって、正 イオンが数回の弹性衝突をくり返してボイド壁面に衝突す る際には、正イオンの持つ運動エネルギーが添加剤分子の 励起作用によって吸収されることも十分に考えられる。

〈3 -4〉添加剤によるボイド壁面の帯電特性の変化による PD減少の可能性実験に使用したアゾベンゼン系添加剤 は、 $\mathrm{Az}$ を除いて、電子供与基あるいは電子受容基が導入さ れている。添加戍分子に付加されている基の種類が変わる 上、添加用を混入したPEの带電特性は変化するものと考え られる ${ }^{(6,7)}$ 。本項では、添加剤によるボイド壁面の带電特性 の変化が PD の減少に及ぼす効果について検討を行う。

図 10 は、PE 表面のクロム球に対する接触帯電特性を、 使用した添加剤毎に示したものである。図10に㧍いて、無 添加 PE 基準に考えると、 $\mathrm{Az}$ 添加の $\mathrm{PE}$ 表面は（図中の $\mathrm{PE}+\mathrm{Az}) 、 ク ロ ム$ 球との接触によって、無添加 $\mathrm{PE}$ 表面より も正に帯電しやすい傾向を示している。すなわち、 $\mathrm{Az}$ 添加

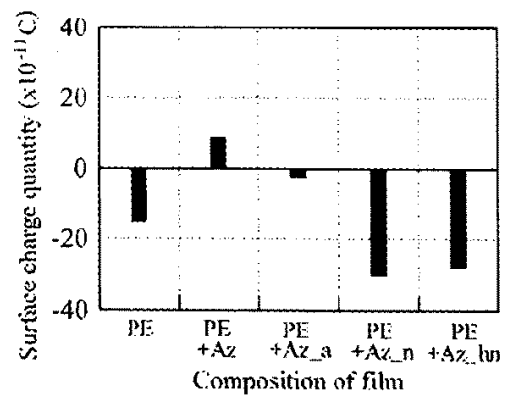

図 10 添加剤入りフィルム表面の帯電電何量 (クロム球との接触後)

Fig.10 Quantity of surface charge on PE film with additive 
の PE は無添加 PE よりも電子を供与しやすく、電子を供与 した後は正極性に带電する性質があるものと考えられる。

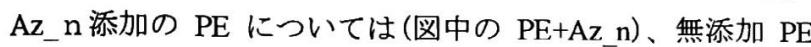
よりも電子を受容しやすく、電子を受容した後は負極性に 帯電する性質があるものと考えられる。使用した他の添加 凨を含めて考えると、Azあるいは Az_a を添加した PE は、 無添加 PEと比べて、電子供与的な性質を示すのに対して、 Az_nあるいは Az_hn 添加の PE は電子受容的な性質を示す 傾向にあることを図10 は示しているものと考えられる。 本実験では、電子供与的な性質の添加剤及び電子受容的 な性質の添加剤のどちらも PD の低减効果が見られた。そ の堿少効果については以下のような説明が可能と考えられ る。まず、電子供与性を示寸ボイド壁について考える。ボ イド壁に正イオン（PD の発生に起因するもの）が付着する と、添加剤から供与される電子と中和し、添加剤が正に帯 電する。ボイド内の電界が反転し、添加剤が正に帯電した 壁面に電子（PD の発生に起因するもの）が付着すると、添 加剂分子と中和するかあるいは電気二重層を形成する。そ のため、この状態で再度ボイド内の電界が反転しても、ボ イド壁から電子はボイド空間へ飛び出しにくいはずである。 次に電子受容性を示す壁面について考える。ボイド壁面に 電子(PD の発生に起因するもの)が付着すると、電子は電子 受容性の添加剂に取り込まれ、添加剤が負に带電する。ボ イド内の電界が反転しても、添加剤に取り込まれた電子は、 ボイド壁面から空間に向かって飛び出しにくいはずである。

以上、アゾベンゼン系添加剤分子がボイド内のPDの低減 効果に果た寸役割について、2つの可能性(励起効果と帯電 特性)を検討した。今後、UV吸収波長が低エネルギ一側にあ り、かつ吸収効率の低い添加剤を使用するなどして、2つ の可能性のうち、どちらが顕著に作用しているかを検討し ていく予定である。

\section{4. まとめ}

本報告では、アゾベンゼン系添加剤によるボイド放電(以 下、PD)の低减効果について検討を行った。以下に、本報告 で得られた事項を番号順にまとめて示す。

(1) 実験に使用した 4 種類すべての添加剤において、添加 剂含んだ PE でコートした PEフィルムを用いると、ボ イド内で発生する PD パルスの発生数及び放電電荷上 もに減少することがわかった。

(2) 添加剂試料による PD の減少効果は、添加濃度につい ては $0.05 〜 0.5 \mathrm{wt} \%$ の範囲で、印加電圧についてはボイ ド放電開始電圧の近傍で顕著に現れた。

(3) 上記(2)の範囲で、添加剤試料における印加電圧 300 サ イクル分の PD の積算放電電荷ならびに積算発生数は、 無添加試料々比較して最大 15 ～20\%にまで堿少した。 この減少効果の添加剂の種類への依存性は顕著には見 られない。

(4) アゾベンゼン系物質の添加により PD が減少する理由
として、添加剤を混入したボイド壁における二次電子 放出の抑制による効果ならびに添加剤混入によるボイ ド壁の帯電特性の変化による効果が考えられる。

(平成 11 年 8 月 27 日受付, 平成 11 年 12 月 2 日再受付)

\section{文献}

(1) 電気学会技術報告第 559 号 "有機複合材料の電気.電子絶縁 人の適用技術の動向”, 電気学会, 第 2 章, 1995 .

(2) 電気学会技術報告( II 部)第 342 号 "固体絶縁材料の添加剤·充 てん剂効果"，電気学会，第 4 章, 1990 .

(3) Stven A. Boggs, "Partial Discharge - Part III: Cavity-Induced PD in Solid Dielectrics", IEEE Electrical Insulation Magazine, Vol.6, No.6, pp.11-20, 1990.

(4) 遠藤, 山野 "アゾベンゼン系添加剤によるPEフィルムの絶 縁破壊強度の上昇"，電気学会論文誌一 A, Vol. 118-A, No. 5, pp. 496-504, 1998.

(5) Y.Yamano, H.Endoh, "Increase in Breakdown Strength of PE Film by Additives of Azocompounds" IEEE Trans. on DEI, Vol.5, No.2, pp.270-275,1998.

(6) 小口, 玉谷 "有機無機粉末の帯電", 静電気学会誌, Vol.7, No.5, pp.292-299, 1983.

(7) 小口, "顔料の帯電", 色材, Vol.58, No.8, pp.476-485, 1985.

(8) Y.Yamano, "Sparks in a Small Gap between HV Sperical Metal Electrode and Corona-charges Organic Film", IEEE Trans. on DEI,

Vol.1, No.3, pp.503-508, 1994.

(9) 山野, "帯電した高分子フィルムと高電圧金属とか作る微小間 隙における放電開始電圧”, 静電気学会誌, Vol.17, No.2, pp.130 $-137,1993$

(10) 新版静電気ハンドブック, 静電気学会編, pp.1027-1029, 1998.

(11) 気体放電現象, 本多, 束京電機大学出版局, p.15, 1978

岡田めぐみ (非会員) 1974 年 4 月30 日生まれ。97 年 3 月 千葉大学教育学部卒業。99年千葉大学大学 院教育学研究科修了。

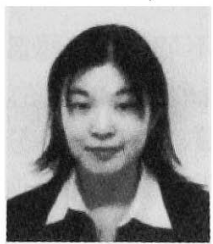

山野 芳昭（正員）1951年 3 月 17 日生まれ。76年 3 月東

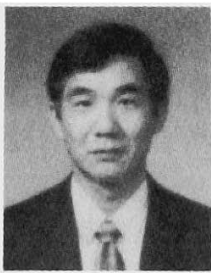
京農工大学大学院工学研究科終了。同年 4 月東洋紡績(株)入社。8 0 年 6 月東京農工大 学工学部助手。 88 年 4 月千葉大学教育学部 講師。同助教授を経て、現在同教授。工学 博士。主として電気絶縁工学、静電気工学 の研究に従事。平成 2 年電気学会論文賞受 賞。電子情報通信学会、静電気学会、IEEE 会員。 